\title{
Correlation between factor VII and PAI-1 genetic variants and recurrent miscarriage
}

\author{
Magdalena Barlik ${ }^{1,2}$, Agnieszka Seremak-Mrozikiewicz ${ }^{1,2}$, Krzysztof Drews ${ }^{1,2}$, \\ Andrzej Klejewski ${ }^{3}$, Grażyna Kurzawińska ${ }^{2}$, Zdzisław Łowicki ${ }^{4}$, Hubert Wolski ${ }^{1}, 5$ \\ ${ }^{1}$ Department of Perinatology and Women's Diseases, Poznan University of Medical Sciences, Poland \\ ${ }^{2}$ Laboratory of Molecular Biology in Division of Perinatology and Women's Diseases, Poznan University of Medical Sciences, \\ Poznan, Poland \\ ${ }^{3}$ Department of Obstetrics and Women's Diseases, Poznan University of Medical Sciences, Poland \\ ${ }^{4}$ Department of Pharmacology and Phytochemistry, Institute of Natural Fibres and Medicinal Plants, Poznan, Poland \\ ${ }^{5}$ Division of Gynecology and Obstetrics, Podhale Multidisciplinary Hospital, Nowy Targ, Poland
}

\begin{abstract}
Background: Polymorphisms which are presented below may be the cause of inherited thrombophilia and may result in pregnancy loss. The hypothesis is based on a number of cardiology studies which have confirmed the involvement of these polymorphisms in thrombotic incidents.

Objectives: To evaluate the role of polymorphisms of factor VII gene (Arg353Gln, $-122 T>C)$ and PAl-1 gene (-675 4G/5G) in the etiology of recurrent miscarriage.

Material and methods: The study group included 152 women with a positive history of $\geq 2$ consecutive pregnancy losses (114 and 38 women with 2 and $\geq 3$ miscarriages, respectively), while 180 healthy women were recruited as controls. Genetic analysis was performed with the use of PCR/RFLP.

Results: Lower frequency of Arg353/Gln353 was observed in women with 2 and $\geq 3$ miscarriages as compared to controls ( $21.1 \%$ vs. $23.9 \%$ and $13.2 \%$ vs. $23.9 \%$, respectively). The frequency of Gln 353 was lower in women with $\geq 3$ miscarriages as compared to controls ( $6.6 \%$ vs. $11.9 \%, p=n s)$. The frequency of $-122 T T$ was higher in women with $\geq 3$ miscarriages as compared to controls $(86.84 \%$ vs. $76.67 \%, p=n s)$, whereas $-122 T C$ was more frequent in controls $(13.16 \%$ vs. $22.78 \%$ in controls, $\mathrm{p}=\mathrm{ns}$ ). The frequency of $-122 \mathrm{~T}$ was higher in patients with $\geq 3$ abortions as compared to controls ( $93.42 \%$ vs. $88.06 \%, p=n s)$, and $-122 \mathrm{C}$ was observed more frequently in controls ( $6.58 \%$ vs. $11.94 \%$ in controls, $p=n s)$. There were no significant differences as far as the $-6754 \mathrm{G} / 5 \mathrm{G}$ polymorphism was concerned.

Conclusions: The obtained results suggest a possible protective role of $G \ln 353$ and $-122 C$ alleles in recurrent miscarriage. Key words: thrombophilia, pregnancy loss, gene polymorphism
\end{abstract}

\section{INTRODUCTION}

The etiology of recurrent miscarriage may be identified in only about $30-50 \%$ of the affected patients. Importantly, numerous studies have already proven the existence of a correlation between inherited thrombophilia and pregnancy loss [1-6]. Standard diagnostic testing for thrombophilia in these patients involves factor V Leiden, $677 \mathrm{C}>T$ MTHFR gene polymorphism, 20210G $>A$ prothrombin gene polymorphism, protein $C$, protein $S$ and antithrombin de- ficiency. However, anticoagulant treatment with heparin and acetylsalicylic acid is successful in the absence of the abovementioned genetic impairments and after exclusion of the antiphospholipid syndrome, suggesting the existence of other genetic variants, which are not included in the basic diagnostic algorithm, conditioning inherited thrombophilia.

Factor VII, together with the tissue factor, takes part in the activation of the exogenous path of clotting and formation of a blood clot after vessel injury. Gene encoding factor 
VII is located on the short arm of chromosome 13 and contains 9 exons ((NM_000131). The majority of the identified factor VII gene polymorphisms are correlated with factor VII deficiency, resulting in exaggerated bleeding and constituting a risk factor for massive hemorrhage. However, several polymorphisms increase factor VII activity and its higher concentration in serum has been described. It may result in an increased risk for thrombotic changes and, in consequence, recurrent miscarriage $[7,8]$.

Plasminogen activator inhibitor-1 (PAI-1) is the main physiological inhibitor of tissue plasminogen activator and urokinase plasminogen activator. It plays a vital role in the regulation of fibrinolytic processes and increased PAI-1 concentration may be the cause of thrombophilia. The gene encoding PAI-1 (SERPINE1) is located on the short arm of chromosome 7 and contains 9 exons (NM_000602). Genetically conditioned changes in PAI- 1 serum concentration and activity may result in hypofibrinolysis, thrombotic changes in the utero-placental unit, and elevated risk for recurrent pregnancy loss. Enhanced PAI-1 secretion by endothelial cells leads to the formation of thrombus in the spiral arteries. Apart from the correlation with recurrent miscarriage, PAl-1 gene polymorphisms may be connected with the development of preeclampsia, gestational hypertension, intrauterine growth restriction, or intrauterine fetal death $[9,10]$.

The aim of our research was to investigate the possibility of a correlation between selected genetic variants of factor VII (Arg353GIn and -122T>C) and PAI-1 (-675 4G/5G) and recurrent miscarriage. Polymorphisms which have been presented below may be the cause of inherited thrombophilia and may result in pregnancy loss. The hypothesis is based on a number of cardiology studies which have confirmed the involvement of these polymorphisms in thrombotic incidents [11-18].

\section{MATERIAL AND METHODS}

All participants (Polish origin, Caucasian race) were recruited at the Department of Perinatology and Wom- en's Diseases, Poznan University of Medical Sciences, between 2011-2013. A total of 152 women (mean age $30.16 \pm 3.82$ years, range $21-45$ years, median 30 years) with a history of $\geq 2$ consecutive miscarriages were enrolled into the study. Spontaneous abortion was defined as the loss of pregnancy before 22 completed weeks of gestation. Patients with known causes of recurrent miscarriage (anatomical anomalies of the genitourinary tract, chromosomal defect, chronic disease, infection, hormonal impairment, antiphospholipid antibodies, thromboembolic disease, cervical insufficiency or other obstetric complications which could cause miscarriage, e.g. hypertension, preeclampsia, eclampsia, gestational diabetes mellitus) were excluded. The study group was subdivided based on the number of spontaneous abortions: 114 with 2 and 38 women with $\geq 3$ consecutive miscarriages.

The control group included 180 women (mean age $29.46 \pm 4.26$ years, range 19-42 years, median 29 years) with a positive history of $\geq 1$ uncomplicated pregnancy (healthy term newborn). All women with a history of miscarriage, other obstetric complications which might be related to thrombotic changes (preeclampsia, fetal hypotrophy, preterm delivery, preterm placental ablation, intrauterine fetal death), thromboembolic disease, and chronic diseases were excluded.

Genotyping of Arg353Gln and -122T>C factor VII gene polymorphisms and - 675 4G/5G PAl-1 gene polymorphism was performed for the entire study population. Genetic analysis was performed with the use of polymerase chain reaction/restriction fragments length polymorphism method (PCR/RFLP). Genomic DNA was extracted from blood leucocytes using QIAamp DNA Blood Mini Kit (QIAGEN Inc., Germany). Starters used for amplification and restriction enzymes used to obtain better resolution for visualization are shown in Table 1. The analysis of the digested fragments was performed using $2 \%$ agarose gel electrophoresis.

Statistical analysis was performed using SPSS 22.0 PL for Windows. Frequencies of genotypes were compared with chi-square test (one-sided Fisher test). The expected

Table 1 Starters and restriction enzymes used in genetic analysis

\begin{tabular}{|c|c|c|c|c|}
\hline & Starters & $\begin{array}{l}\text { Restriction } \\
\text { enzyme }\end{array}$ & $\begin{array}{l}\text { Recognized } \\
\text { sequence }\end{array}$ & Digested fragments \\
\hline Arg353Gln & $\begin{array}{l}\text { F 5'-GGG AGA CTC CCC AAA TAT CAC-3' } \\
\text { R 5'-ACG CAG CCT TGG CTT TCT CTC-3' }\end{array}$ & $\begin{array}{l}\text { Mspl } \\
\text { (EURx) }\end{array}$ & $C \wedge \mathrm{CGG}$ & $\begin{array}{l}\text { Arg353/Arg353 - 206, 67, } 39 \text { bp } \\
\text { Arg353/GIn353 - 273, 206, 67, } 39 \text { bp } \\
G \ln 353 / G \ln 353-273,39 b p\end{array}$ \\
\hline$-122 T>C$ & $\begin{array}{l}\text { F 5'-TCG CAT GAT TGC TAT GGG AC-3' } \\
\text { R 5'-GTT GAC ATT CCC CAT GGG AC- } 3^{\prime}\end{array}$ & $\begin{array}{l}\text { Sdul (Bsp1286l) } \\
\text { (Thermo Scientific) }\end{array}$ & $\mathrm{GDGCH} \wedge \mathrm{C}$ & $\begin{array}{l}-122 T T-200(210), 156 \mathrm{bp} \\
-122 T C-200(210), 156,90,66 \mathrm{bp} \\
-122 C \mathrm{C}-200(210), 90,66 \mathrm{bp}\end{array}$ \\
\hline$-6754 G / 5 G$ & $\begin{array}{l}\text { 5'-GCC CTC AGG GGC ACA GAG AGA GTC TGG CCA-3' } \\
5^{\prime} \text {-GCA ATG CAG CCA GCC ACG TG - } 3^{\prime}\end{array}$ & $\begin{array}{l}\text { Bsll } \\
\text { (Thermo Scientific) }\end{array}$ & CCNNNNN^NNGG & $\begin{array}{l}-6754 G 107,56 b p \\
-6755 G 74,56,34 b p\end{array}$ \\
\hline
\end{tabular}


genotype frequencies were calculated from allele frequencies with the Hardy-Weinberg equation.

All patients gave their written confirmed consent for the study. Local Ethics Committee approved of the study (no. 422/11).

\section{RESULTS}

\section{Arg353GIn factor VII gene polymorphism}

The frequency of the Arg353/Arg353 genotype was slightly higher in women with 2 miscarriages $(78.0 \%$ vs. $76.1 \%$ in controls, p = ns). The Arg353/Gln353 genotype was observed more frequently in controls as compared to women with 2 pregnancy losses ( $21.1 \%$ vs. $23.9 \%$ in controls, $p=n s$ ). The mutated Gln353/Gln353 genotype was present only in 1 patient from that subgroup and in none of the controls $(0.9 \%$ vs. $0.0 \%$ in controls, $p=n s)$. There were no statistically significant differences in the frequency of alleles between both analyzed groups (Arg353: $88.6 \%$ vs. $88.1 \%$ in controls, $\mathrm{p}=\mathrm{ns} ; \mathrm{Gln} 353 \mathrm{i}: 11.4 \%$ vs. $11.9 \%$ in controls, $\mathrm{p}=\mathrm{ns}$ ) (Table 2).

The differences between genotype and allele frequencies were more clear between the group with $\geq 3$ miscarriages and controls. The homozygotic Arg353/Arg353 genotype was slightly more frequent in the group with $\geq 3$ miscarriages $(86.8 \%$ vs. $76.1 \%$ in controls, $p=n s)$. The study revealed an overrepresentation of heterozygotic Arg353/Gln353 genotype in controls ( $23.9 \%$ in controls vs. $13.2 \%, p=n s)$. The frequency of the Arg353 allele was slightly higher in the group with $\geq 3$ spontaneous abortions $(93.4 \%$ vs. $88.1 \%$ in controls, $\mathrm{p}=\mathrm{ns}$ ) and the mutated $\mathrm{Gln} 353$ allele was more frequent in controls ( $11.9 \%$ in controls vs. $6.6 \%, p=n s$ ) (Table 2 ).

\section{$-122 T>C$ factor VII gene polymorphism}

The frequency of genotypes and alleles of the $-122 T>C$ polymorphism was similar in the group with 2 miscarriages and in controls ( -122 TT: $78.07 \%$ vs. $76.67 \%$ in controls, $p=n s$; -122 TC: $20.18 \%$ vs. $22.78 \%$ in controls, $p=n s ;-122 C$ : $1.75 \%$ vs. $0.55 \%$ in controls, $p=n s ;-122 T: 88.16 \%$ vs. $88.06 \%$ in controls, $p=n s ;-122 C: 11.84 \%$ vs. $11.94 \%$ in controls, $p=n s$ ) (Table 3).

Slightly higher frequency of the homozygotic -122TT genotype was observed in the group with $\geq 3$ pregnancy losses ( $86.84 \%$ vs. $76.67 \%$ in controls, $p=n s)$, and the heterozygotic -122 TC genotype was found more frequently in controls than in women with $\geq 3$ miscarriages $(13.16 \%$ vs. $22.78 \%$ in controls, $p=n s) .-122$ T allele was more frequent in the study group of women with 3 or more miscarriages (93.42\% vs. $88.06 \%$ in controls, $\mathrm{p}=\mathrm{ns}$ ) and the mutated $-122 \mathrm{C}$ allele - in controls $(6.58 \%$ vs. $11.94 \%$ in controls, $\mathrm{p}=\mathrm{ns}$ ) (Table 3).

\section{-675 4G/5G PAI-1 gene polymorphism}

The frequency of genotypes and alleles was comparable in the group with 2 miscarriages and in controls (-675 4G/-675 4G: $32.5 \%$ vs. $35.0 \%$, p = ns; -675 4G/-675 5G: $49.1 \%$ vs. $47 . \%, p=n s ;-6755 G /-6755 G: 18.4 \%$ vs. $17.8 \%$, $p=n s ;$ allele $-6754 G: 57.0 \%$ vs. $58.6 \%, p=n s ;-6755 G: 43.0 \%$ vs. $41.4 \%, p=n s$ ) (Table 4). Similar observation was made for the group with $\geq 3$ pregnancy losses $(-6754 \mathrm{G} /-6754 \mathrm{G}$ : $34.2 \%$ vs. $35.0 \%, p=n s ;-6754 G /-675$ 5G: $50.0 \%$ vs. $47.2 \%$, $\mathrm{p}=\mathrm{ns} ;-675$ 5G/-675 5G: $15.8 \%$ vs. $17.8 \%, \mathrm{p}=\mathrm{ns}$; allele $-6754 G: 59.2 \%$ vs. $58.6 \%$, p = ns; -675 5G: $40.8 \%$ vs. $41.4 \%$, $\mathrm{p}=\mathrm{ns}$ ) (Table 4).

Table 2. The frequency of genotypes and alleles of the Arg $353 \mathrm{Gln}$ factor VII gene polymorphism in the groups with a history of 2 and $\geq 3$ miscarriages

\begin{tabular}{|c|c|c|c|c|c|c|c|c|c|c|}
\hline \multirow{3}{*}{$\begin{array}{l}\text { Arg353Gln } \\
\text { Genotypes }\end{array}$} & \multicolumn{8}{|c|}{$\begin{array}{l}\text { Study group } \\
(n=152)\end{array}$} & \multirow{2}{*}{\multicolumn{2}{|c|}{$\begin{array}{l}\text { Control group } \\
(n=180)\end{array}$}} \\
\hline & \multicolumn{4}{|c|}{$\begin{array}{c}2 \text { miscarriages } \\
(n=114)\end{array}$} & \multicolumn{4}{|c|}{$\begin{array}{l}\geq 3 \text { miscarriages } \\
\quad(n=38)\end{array}$} & & \\
\hline & $\begin{array}{l}\text { Observed } \\
\text { value } \\
\mathrm{n}[\%]\end{array}$ & $\begin{array}{l}\text { Expected } \\
\text { value } \\
\text { [\%] }\end{array}$ & OR & $\mathbf{P}$ & $\begin{array}{l}\text { Observed } \\
\text { value } \\
\mathrm{n}[\%]\end{array}$ & $\begin{array}{c}\text { Expected } \\
\text { value } \\
{[\%]}\end{array}$ & OR & $\mathbf{P}$ & $\begin{array}{l}\text { Observed } \\
\text { value } \\
\mathrm{n}[\%]\end{array}$ & $\begin{array}{c}\text { Expected } \\
\text { value } \\
{[\%]}\end{array}$ \\
\hline $\operatorname{Arg} 353 / \operatorname{Arg} 353$ & $89(78.0)$ & 78.5 & 1.12 & 0.40 & $33(86.8)$ & 87.2 & 2.07 & 0.10 & $137(76.1)$ & 77.5 \\
\hline Agr353/Gln353 & $24(21.1)$ & 20.2 & 0.85 & 0.34 & $5(13.2)$ & 12.3 & 0.48 & 0.10 & $43(23.9)$ & 21.1 \\
\hline$G \ln 353 / G \ln 353$ & $1(0.9)$ & 1.3 & - & 0.39 & $0(0.00)$ & 0.5 & - & 1 & $0(0.0)$ & 1.4 \\
\hline Total & $114(100.0)$ & 100 & & & $38(100.0)$ & 100.0 & & & $180(100.0)$ & 100 \\
\hline \multicolumn{11}{|l|}{ Alleles } \\
\hline $\operatorname{Arg} 353$ & $202(88.6)$ & - & 1.05 & 0.48 & $71(93.4)$ & - & 1.93 & 0.12 & $317(88.1)$ & - \\
\hline$G \ln 353$ & $26(11.4)$ & - & 0.95 & 0.48 & $5(6.6)$ & - & 0.52 & 0.12 & $43(11.9)$ & - \\
\hline Total & $228(100.0)$ & - & & & $76(100.0)$ & - & & & $360(100.0)$ & - \\
\hline
\end{tabular}

Analyzed subgroups were compared to the control group 
Table 3. The frequency of genotypes and alleles of the -122T>C factorVII gene polymorphism in the groups with a history of 2 and $\geq 3$ miscarriages

\begin{tabular}{|c|c|c|c|c|c|c|c|c|c|c|}
\hline \multirow{3}{*}{$\begin{array}{l}-122 T>C \\
\text { Genotypes }\end{array}$} & \multicolumn{8}{|c|}{$\begin{array}{l}\text { Study group } \\
(n=152)\end{array}$} & \multirow{2}{*}{\multicolumn{2}{|c|}{$\begin{array}{l}\text { Control group } \\
(n=180)\end{array}$}} \\
\hline & \multicolumn{4}{|c|}{$\begin{array}{l}2 \text { miscarriages } \\
(n=114)\end{array}$} & \multicolumn{4}{|c|}{$\begin{array}{c}\geq 3 \text { miscarriages } \\
\quad(n=38)\end{array}$} & & \\
\hline & $\begin{array}{l}\text { Observed } \\
\text { value } \\
\mathrm{n}[\%]\end{array}$ & $\begin{array}{l}\text { Expected } \\
\text { value } \\
{[\%]}\end{array}$ & OR & $\mathbf{P}$ & $\begin{array}{c}\text { Observed } \\
\text { value } \\
\mathrm{n}[\%]\end{array}$ & $\begin{array}{c}\text { Expected } \\
\text { value } \\
\text { [\%] }\end{array}$ & OR & $\mathbf{P}$ & $\begin{array}{l}\text { Observed } \\
\text { value } \\
\text { n [\%] }\end{array}$ & $\begin{array}{c}\text { Expected } \\
\text { value } \\
{[\%]}\end{array}$ \\
\hline$T T$ & 89 (78.07) & 77.72 & 1.08 & 0.45 & $33(86.84)$ & 87.27 & 2.01 & 0.12 & 138 (76.67) & 77.54 \\
\hline TC & $23(20.18)$ & 20.88 & 0.86 & 0.35 & $5(13.16)$ & 12.29 & 0.51 & 0.13 & 41 ( 22.78$)$ & 21.03 \\
\hline CC & $2(1.75)$ & 1.40 & 3.20 & 0.33 & $0(0.00)$ & 0.43 & $\otimes$ & 0.83 & $1(0.55)$ & 1.43 \\
\hline Total & $114(100.0)$ & 100.0 & & & $38(100.0)$ & 100.0 & & & $180(100.00)$ & 100 \\
\hline \multicolumn{11}{|l|}{ Alleles } \\
\hline$T$ & 201 (88.16) & - & 1.01 & 0.54 & 71 (93.42) & - & 1.93 & 0.12 & $317(88.06)$ & - \\
\hline C & $27(11.84)$ & - & 0.99 & 0.54 & $5(6.58)$ & - & 0.52 & 0.12 & $43(11.94)$ & - \\
\hline Total & $228(100.0)$ & - & & & $76(100.0)$ & - & & & $360(100.0)$ & - \\
\hline
\end{tabular}

Analyzed subgroups were compared to the control group

\begin{tabular}{|c|c|c|c|c|c|c|c|c|c|c|}
\hline \multirow{3}{*}{$\begin{array}{l}-675 \text { 4G/5G } \\
\text { Genotypes }\end{array}$} & \multicolumn{8}{|c|}{$\begin{array}{l}\text { Study group } \\
\qquad(n=152)\end{array}$} & \multirow{2}{*}{\multicolumn{2}{|c|}{$\begin{array}{l}\text { Control group } \\
\quad(n=180)\end{array}$}} \\
\hline & \multicolumn{4}{|c|}{$\begin{array}{c}2 \text { miscarriages } \\
(n=114)\end{array}$} & \multicolumn{4}{|c|}{$\begin{array}{c}\geq 3 \text { miscarriages } \\
\quad(n=38)\end{array}$} & & \\
\hline & $\begin{array}{l}\text { Observed } \\
\text { value } \\
\text { n [\%] }\end{array}$ & $\begin{array}{l}\text { Expected } \\
\text { value } \\
\text { [\%] }\end{array}$ & OR & $\mathbf{P}$ & $\begin{array}{c}\text { Observed } \\
\text { value } \\
n[\%]\end{array}$ & $\begin{array}{c}\text { Expected } \\
\text { value } \\
{[\%]}\end{array}$ & OR & $\mathbf{P}$ & $\begin{array}{l}\text { Observed } \\
\text { value } \\
\text { n [\%] }\end{array}$ & $\begin{array}{c}\text { Expected } \\
\text { value } \\
{[\%]}\end{array}$ \\
\hline $4 G / 4 G$ & 37 (32.5) & 32.5 & 0.89 & 0.37 & $13(34.2)$ & 35.0 & 0.97 & 0.54 & $63(35.0)$ & 34.4 \\
\hline $4 G / 5 G$ & $56(49.1)$ & 49.0 & 1.08 & 0.42 & $19(50.0)$ & 48.3 & 1.12 & 0.45 & 85 (47.2) & 48.5 \\
\hline $5 G / 5 G$ & $21(18.4)$ & 18.5 & 1.04 & 0.50 & $6(15.8)$ & 16.7 & 0.87 & 0.49 & $32(17.8)$ & 17.1 \\
\hline Total & $114(100.00)$ & $114(100.0)$ & & & $38(100.0)$ & $38(100.0)$ & & & $180(100.0)$ & 100 \\
\hline \multicolumn{11}{|l|}{ Alleles } \\
\hline $4 G$ & $130(57.0)$ & - & 0.94 & 0.38 & $45(59.2)$ & - & 1.03 & 0.51 & 211 (58.6) & - \\
\hline $5 G$ & $98(43.0)$ & - & 1.07 & 0.38 & $31(40.8)$ & - & 0.98 & 0.51 & 149 (41.4) & - \\
\hline Total & $228(100.0)$ & - & & & $76(100.0)$ & - & & & $360(100.0)$ & - \\
\hline
\end{tabular}

Analyzed subgroups were compared to the control group

\section{DISCUSSION}

\section{Arg353GIn factor VII gene polymorphism}

To the best of our knowledge, there has been only one report on the correlation of the Arg353GIn factor VII gene polymorphism and the risk of recurrent miscarriage, i.e. the study by Seremak-Mrozikiewicz et al. [7], so far. Our study has been the second analysis on the correlation between the Arg353GIn factor VII gene polymorphism and recurrent pregnancy loss. Seremak-Mrozikiewicz et al., based their research hypothesis on a number of cardiology reports, suggesting the existence of a correlation between the abovementioned genetic variant and elevated risk for cardiovascular disease. It is believed that the presence of the mutated Gln353 allele leads to decreased concentration and activity of factor VII, resulting in lower intensity of coagulation cascade and reduced risk for thrombotic changes [7, 19].

In the cited paper (by Seremak-Mrozikiewicz), the study group included 104 patients with $\geq 2$ miscarriages between 6-13 weeks of gestation and 163 healthy controls with a negative history of pregnancy loss and a positive history of $\geq 1$ uncomplicated pregnancy (healthy newborn at term). Their study revealed a slightly higher frequency of the $\operatorname{Arg} 353 / \operatorname{Arg} 353$ genotype in the study group (89.69\% 
vs. $74.5 \%$ in controls, $p=0.086$ ). Moreover, overrepresentation of the $\mathrm{Arg} 353 / \mathrm{Gln} 353$ genotype was observed in controls ( $17.31 \%$ vs. $25.15 \%$ in control group, $p=0.086$ ). The frequency of the mutated $\mathrm{Gln} 353$ allele was also higher in controls (12.58\% in controls vs. $8.65 \%, p=0.101)$. Further analysis revealed a lower frequency of the Arg353/Gln353 genotype in the group with 2 miscarriages, as well as $w \geq 3$ miscarriages as compared to controls (respectively, $16.25 \%$ and $20.83 \%$ vs. $25.15 \%$ ) [7].

The obtained results suggest a possible protective role of the mutated GIn353 allele of the Arg353G/n factor VII gene polymorphism in recurrent miscarriage. Similar conclusions were reported by Seremak-Mrozikiewicz et al.

\section{$-122 T>C$ factor VII gene polymorphism}

To the best of our knowledge, the literature offers no reports on the correlation between -122T>C factor VII gene polymorphism and recurrent miscarriage and our study has been the first on the topic in question. It points out a possible protective role of the mutated $-122 \mathrm{C}$ allele of the $-122 T>C$ factor VII gene polymorphism in the occurrence of recurrent abortions, especially in women with $\geq 3$ pregnancy losses. It is indicated by a slightly higher frequency of the -122 TT genotype in the group with $\geq 3$ miscarriages $(86.84 \%$ vs. $76.67 \%$ in controls, $p=0.12$ ) and overrepresentation of the -122 TC genotype in controls $(13.16 \%$ vs. $22.78 \%$ in controls, $p=0.13$ ). Moreover, the frequency of the $-122 T$ allele was higher in the group with $\geq 3$ pregnancy losses $(93.42 \%$ vs. $88.6 \%$ in controls, $p=0.12$ ) and the mutated -122 Callele was noted more frequently in controls $(6.58 \%$ vs. $11.94 \%$ in controls, $p=0.12$ ).

\section{-675 4G/5G PAl-1 gene polymorphism}

The abovementioned polymorphism is one of the most often studied PAI-1 functional genetic variants as far as its correlation with obstetric complications is concerned. The -675 4G allele determines increased PAI- 1 concentration and enhanced prothrombotic activity. The $-6754 \mathrm{G} / 5 \mathrm{G}$ polymorphism has been suggested to be involved in the etiology of intrauterine fetal death, intrauterine growth restriction, preterm placental abruption, recurrent miscarriage, and preeclampsia [20, 21].

Increased PAI-1 concentration and reduction of fibrinolysis is observed in carriers of the homozygotic - $6754 \mathrm{G} /-6754 \mathrm{G}$ genotype as compared to carriers of the $-6755 G /-6755 G$ genotype. Intermediate value of the PAI- 1 concentration is noted in carriers of the heterozygotic $-6754 \mathrm{G} /-6755 \mathrm{G}$ genotype. So, it is believed that the mutated $-6755 \mathrm{G}$ allele may play a protective role in recurrent pregnancy loss. In our study, no significant differences between the analyzed groups were observed. The conducted analysis did not re- veal any correlation of the -6754 G/5G PAI- 1 gene polymorphisms with the risk of recurrent miscarriage. However, numerous contemporary studies have confirmed the influence of the abovementioned genetic variant on elevated risk for recurrent pregnancy loss.

The aim of the research by Subrt et al., was to evaluate the frequency of genotypes and alleles of the $-6754 \mathrm{G} /$ 6755 G PAl-1 gene polymorphism and its correlation with the presence of antiphospholipid antibodies in a group of 157 women with a positive history of recurrent spontaneous abortion. The study revealed a statistically significant connection between this obstetric complication and the $-6754 G /-6754 G$ genotype. Regardless, no correlation with the presence of antiphospholipid antibodies was found [22].

The study by Ivanov et al., also suggests an independent role of the $-6754 \mathrm{G} /-6755 \mathrm{G}$ PAI-1 gene polymorphism in the etiology of recurrent pregnancy loss. Their study population included 110 women with a history of recurrent miscarriage and 97 healthy controls. These authors evaluated the frequency of the $-6754 \mathrm{G} /-6755 \mathrm{G} \mathrm{PAl}-1$ gene polymorphism, 20210G >A prothrombin gene polymorphism, 677C > TMTHFR gene polymorphism and factor $V$ Leiden. Higher frequency of the -6754 G/-675 5G PAl-1 gene polymorphism was noted in the study group ( $41.8 \%$ vs. $26.8 \%$, WR $1.96 ; p=0.034$ ). Moreover, this difference remained significant even after the exclusion of the carriers of the $20210 \mathrm{G}>A$ prothrombin gene polymorphism, 677C $>$ T MTHFR gene polymorphism and factor $V$ Leiden from the analysis [23].

Coulam et al., conducted a very interesting analysis on genetically conditioned thrombophilia and its correlation with recurrent pregnancy loss. These authors based their hypothesis on the well-documented fact that inherited thrombophilia constitutes a risk factor for cardio-vascular diseases and obstetric complications. The aim of their study was to compare the frequency of nine mutations correlated with thrombophilia in a group of 550 women with a history of recurrent miscarriage, in 43 patients with deep vein thrombosis, and in 41 healthy controls. Each patient was genotyped for the presence of the $1691 \mathrm{G}>A$ and $H 1299 R$ factor $V$ gene polymorphism, 20210G $>A$ prothrombin gene polymorphism, V34L factor XIII gene polymorphism, $-455 \mathrm{G}>A$ beta-fibrinogen gene polymorphism, $677 C>$ T and $1298 A>C$ MTHFR gene polymorphism, and - 675 4G/5G PAl-1 gene polymorphism. The frequency of all genetic variants was higher in patients with deep vein thrombosis as compared to controls and women with recurrent miscarriage. The V34L factor XIII gene polymorphism and -675 4G/5G PAI-1 gene polymorphism were statistically more often observed in the group with pregnancy loss as compared to controls. These authors concluded that basic testing for thrombophilia should also include the -675 4G/5G PAI-1 gene polymorphism [24]. 


\section{CONCLUSIONS}

1. The obtained results suggest a possible protective role of the mutated Gln353 allele of the Arg353Gln factor VII gene polymorphism in recurrent miscarriage.

2. The present study points out a possible protective role of the mutated $-122 \mathrm{C}$ allele of the $-122 \mathrm{~T}>\mathrm{C}$ factor VII gene polymorphism as far as the occurrence of recurrent abortion is concerned, especially in the group with $\geq 3$ pregnancy losses.

3. The analysis did not reveal any correlations between -675 4G/5G PAl-1 gene polymorphisms and the risk for recurrent miscarriage.

4. A correlation between thrombophilia and recurrent miscarriage has been observed by numerous authors. However, the pathological mechanisms involved in the process remain poorly understood. The etiology of recurrent pregnancy loss is multifactorial and efficient treatment remains a challenge. Further studies are essential in order to obtain strong evidence.

\section{REFERENCES}

1. Practice Committee of the American Society for Reproductive Medicine. Evaluation and treatment of recurrent pregnancy loss: a committee opinion. Fertil Steril. 2012, 98, 1103-1111.

2. Barlik M, Seremak-Mrozikiewicz A, Kraśnik W, [et al.]. The $20210 G>A$ i $19911 A>G$ polymorphisms of prothrombin gene and recurrent miscarriages. Ginekol Pol. 2013, 84, 830-834.

3. Kurzawińska G, Seremak-Mrozikiewicz A, Drews K, [et al.]. Genetic conditioned changes in activity of 5,10-methylenetetrahydrofolate reductase (MTHFR) and recurrent miscarriages. Ginekol Pol. 2009, 80, 762-767.

4. Kurzawińska G, Seremak-Mrozikiewicz A, Drews K, [et al.]. Inherited thrombophilia as the reason of recurrent miscarriages in the first trimester of pregnancy. Ginekol Pol. 2009, 80, 657-663.

5. Di Micco P, D'uva M, Strina I, [et al.]. Recurrent pregnancy loss and thrombophilia. Clin Lab. 2007, 53, 309-314.

6. Seremak-Mrozikiewicz A, Drews K, Kurzawińska G, [et al.]. The significance of $1793 \mathrm{G}>\mathrm{A}$ polymorphism in MTHFR gene in women with first trimester recurrent miscarriages. Neuro Endocrinol Lett. 2010, 31, 717-723.

7. Seremak-Mrozikiewicz A, Drews K, Kurzawińska G, [et al.]. The connection between Arg353GIn polymorphism of coagulation factor VII and recurrent miscarriages. Ginekol Pol. 2009, 80, 8-13.
8. Barlik M, Seremak-Mrozikiewicz A, Wolski $\mathrm{H}$, [et al.]. The -323P0/P10 factor VII gene polymorphism and the risk of recurrent miscarriage. Ginekol Pol. 2014, 85, 594-599.

9. Belo L, Santos-Silva A, Rumley A, [et al.]. Elevated tissue plasminogen activator as a potential marker of endothelial dysfunction in pre-eclampsia: correlation with proteinuria. BJOG. 2002, 109, 1250-1255.

10. Chambers JC, Fusi L, Malik IS, [et al.]. Association of maternal endothelial dysfunction with preeclampsia. JAMA. 2001, 285, 1607-1612.

11. Abboud N, Ghazouani L, Saidi S, [et al.]. Association of PAI-1 4G/5G and -844G/A gene polymorphisms and changes in PAI-1/tissue plasminogen activator levels in myocardial infarction: a case-control study. Genet Test Mol Biomarkers. 2010, 14, 23-27.

12. Ferrara F, Meli F, Raimondi F, [et al.]. The association between the $4 \mathrm{G} / 5 \mathrm{G}$ polymorphism in the promoter of the plasminogen activator inhibitor-1 gene and extension of postsurgical calf vein thrombosis. Blood Coagul Fibrinolysis. 2013, 24, 237-242.

13. Saidi S, Slamia LB, Mahjoub T, [et al.]. Association of PAI-1 4G/5G and -844G/A gene polymorphism and changes in PAI-1/tPA levels in stroke: a case-control study. J Stroke Cerebrovasc Dis. 2007, 16, 153-159.

14. Ekström M, Silveira A, Bennermo M, [et al.]. Coagulation factor VII and inflammatory markers in patients with coronary heart disease. Blood Coagul Fibrinolysis. 2007, 18, 473-477.

15. Fujimaki T, Kato K, Yoshida T, [et al.]. Association of genetic variants with myocardial infarction in Japanese individuals with chronic kidney disease. Thromb Haemost. 2009, 101, 963-968.

16. Mo X, Hao Y, Yang X, [et al.]. Association between polymorphisms in the coagulation factor VII gene and coronary heart disease risk in different ethnicities: a meta-analysis. Medical Genetics. 2011, 12, 107.

17. Pushkov AA, Blagodatskikh KA, Nikitin AG, [et al.]. Polymorphic markers Ala455Val of the THBD gene and Arg353GIn of the F7 gene and association with unfavorable outcomes of coronary atherosclerosis in patients with a history of acute ischemic heart disease. Genetika. 2011, 47, 1386-1392.

18. Wu AH, Tsongalis GJ. Correlation of polymorphisms to coagulation and biochemical risk factors for cardiovascular diseases. Am J Cardiol. 2001, 87, 1361-1366.

19. Mrozikiewicz P, Cascorbi I, Ziemer S, [et al.]. Reduced procedural risk for coronary catheter interventions in carriers of the coagulation factor VII-GIn353 gene. J Am Coll Cardiol. 2000, 36, 1520-1525.

20. Glueck CJ, Kupferminc MJ, Fontaine RN, [et al.]. Genetic hypofibrinolysis in complicated pregnancies. Obstet Gynecol. 2001, 97, 44-48.

21. Yamada N, Arinami T, Yamakawa-Kobayashi K, [et al.. The 4G/5G polymorphism of the plasminogen activator inhibitor-1 gene is associated with severe preeclampsia. J Hum Genet. 2000, 45, 138-141.

22. Subrt I, Ulcova-Gallova Z, Cerna M, [et al.]. Recurrent pregnancy loss, plasminogen activator inhibitor-1 (-675) 4G/5G polymorphism and antiphospholipid antibodies in Czech women. Am JReprod Immunol.2013,70, 54-58.

23. Ivanov $\mathrm{P}$, Komsa-Penkova $\mathrm{R}$, Ivanov I, [et al.]. Plasminogen activator inhibitor type 1 activity in women with unexplained very early recurrent pregnancy loss. Akush Ginekol (Sofiia). 2010, 49, 3-8.

24. Coulam CB, Wallis D, Weinstein J, [et al.]. Comparison of thrombophilic gene mutations among patients experiencing recurrent miscarriage and deep vein thrombosis. Am J Reprod Immunol. 2008, 60, 426-431. 